\title{
SELECTED ASPECTS OF DEMOGRAPHIC CHANGES AND ITS IMPACT ON THE LABOR MARKET AND EDUCATION
}

\author{
Ryszard MARSZOWSKI ${ }^{1 *}$, Leszek DROBEK ${ }^{2}$ \\ ${ }^{1}$ Central Mining Institute, Katowice; rmarszowski@gig.eu, ORCID: 000000022855-7121 \\ ${ }^{2}$ Central Mining Institute, Katowice; Idrobek@gig.eu, ORCID: 0000-0003-2114-089X \\ * Correspondence author
}

Purpose: the main purpose of the article is to justify the need for rational inclusion in the scientific and economic policy of scientific assessments and analyzes of the effects of demographic changes on labor resources and Poland's educational system.

Design/methodology: theses presented in the article have been verified using literature review, critical literature analysis, documentary analysis, statistical descriptive analysis.

Findings: Based on the content of this article, it can be stated that the effect of regressive demographic change due to the ongoing process of aging of the society will affect the labor market and education. In this light, the main challenge facing the European Union and Poland is to ensure a properly educated and skilled society that will effectively use their potential to achieve the assumed social and economic goals.

Originality: the article enriches knowledge and develops discussion in the area of need to build a modern education system that responds to contemporary and future challenges. This is a system that, in line with economic goals and megatrends, will determine the successful development of the two most important attributes of human and social capital in the modern world - the universality of ideas and a dynamic competent society.

Keywords: human, labor market, education, demographic change.

Category of the paper: Conceptual paper ${ }^{1}$.

\section{Introduction}

According to demographic projections, by 2030, the number of people of working age in the European Union will drop by almost 21 million. Hence, the population of young Europeans will decrease by $20 \%$ over the next 20 years. This change is one of the key challenges in the

\footnotetext{
${ }^{1}$ The article is the result of research carried out by the Central Mining Institute on behalf of the "KADRA" Trade Union Agreement and the Trade Union Forum as part of the project entitled "A competent trade unionist - how to support employees in labor change processes" co-financed by the European Social Fund under the Operational Program Knowledge Education Development 2014-2020.
} 
area of education for contemporary Europe. This is very clearly noted by the European Network of Education Economics Experts (EENEE), who, in the report "The future of European education and training systems: key challenges" (The Future of European Education and Training Systems: Key Challenges and Their Implications) (Schlotter et al., 2008) states that among the four key challenges for education and training systems - indirectly labor markets demographic change comes first. The vision of future development described in this way includes knowledge resulting from observations, analyzes and forecasts that surround reality. In this light, taking into account the fact that forecasting is predicting the future in a rational way using scientific methods and that prediction is forecasting based on an econometric model, action based solely on the observed state of the phenomenon prevents the development of horizontal goals. In view of these regularities, the need for prognostic works is irrefutable. In these, it is assumed that the forecast is a court formulated with the use of scientific achievements related to a specific future that is empirically verifiably uncertain (Forecasting and simulations..., 2019).

One should not overlook the determinants that shape current and future labor market policies, particularly the aforementioned issue of the depth of demographic changes experienced by the modern world. The indicated changes make their rational consideration in demographic and economic policy, one of the currently most difficult challenges on a global and local scale (Mączyńska, 2010, p. 15). Therefore, the background of socio-demographic changes should pay attention not only to the economic aspect, but also to the effects upon the labor market.

\section{Demographic changes - theoretical aspect}

Against the background of the above remarks, it is worth reminding the reader here that it was the French demographer Adolphe Landry (1909) who at the beginning of the 20th century developed a theoretical concept explaining the demographic development of the world. Over time, the concept took several characteristic names, such as demographic transformation, phase development or cyclical demographic transition (Blacker et al., 1947, pp. 88-101). Despite this work, the basic assumptions shaping Landry's ideas have not changed. Accordingly, the development of the population for each large social group follows several successive time phases, differentiated due to the characteristic development of the natural movement of the population determined by the number of births and deaths. This process throughout history - from a society living in primitive conditions, to a society operating in a globalized world and rich knowledge-based economies - is universal. Demographers, attempting to explain the sources and implications associated with changes in the quantitative and qualitative structure of the natural movement of the population, distinguish five key stages of its development: 
Phase I - means a small demographic increase. It is characteristic of peoples living at a low level of economic development, and is notable for having a very high birth rate associated with an equally high level of mortality. This condition determines the very low survival rate, which in socially and economically critical situations (widespread hunger, armed conflicts or mass epidemics) takes the form of a large natural loss. In this phase, the average life expectancy is very low and does not exceed 30 years - while also very high in the total population of the percentage of children. Phase II - is determined by an intensive demographic increase with a simultaneous - still high - percentage of births, however, which is characterized by a noticeable, though small, drop. Still, as a result of the development of medicine, hygiene and improving living conditions, a decrease in the death rate is clearly evident. As a result, the population turnover is very high. The period in which the described processes take place, is called a demographic explosion or a sudden increase in population. Phase III - is a time of moderate demographic growth. This is the period in which the traditional multigenerational family model is slowly disappearing. Moreover, the number of births is systematically falling, while the mortality rate is falling. Natural increase is decreasing, but remains at a level that secures replacement of generations. Moreover, the average life expectancy increases with the appearance of symptoms of an aging population. The percentage of people at a young age is still high in this phase. Phase IV - is characterized by demographic stagnation. In this phase, the process of a further decline in the number of births, while the number of deaths remaining at a constant level, is observed. As a result of the changes taking place, the natural increase gradually approaches zero. Aging is increasingly evident, with the average life expectancy increasing significantly to 80 years. Phase $\mathrm{V}$ is a time of demographic decline. In this last phase of demographic change, the number of births is clearly lower than deaths. Natural depletion complements the influx of migrants, determining serious phenomena and political and social problems. Population aging is a dynamic phenomenon associated with the reversal of the age pyramid. The population of the working age population is clearly decreasing with the simultaneous dynamic growth of the post-working age population and the population of people over 75 years of age.

The indicated phenomena associated with the fourth and fifth phase of demographic development are currently shaping social relations in economically developed countries. This fact and the consequences resulting from it determine the emergence in demography of new theoretical hypotheses and research questions directly related to the relations between the size of births and deaths. Based on these relationships, a new approach was created in describing demographic phenomena, termed the "Second Demographic Transition". This approach distinguishes four characteristic determinants, which, according to the creator of this theory D. van de Kaa (1987, p. 11), are:

- decreasing the importance of marriage as a form of human co-habitation for cohabitation,

- transition from the traditional family model, 
- the transition from preventive contraception to conscious procreation,

- transition from homogeneous types of families and households to various forms.

In the context of the regularities described, it is worth reflecting on the definition of aging and/or old age. As it is noted in the report on the situation of older people in Poland, the concept of old age and aging can be considered in two ways - in the individual aspect and as phenomena regarding the population of these units, i.e. the society of a given region, country, part of the world (Report..., 2012, pp. 15-18). In the individual aspect, old age is part of a biological phenomenon that makes up the human life cycle (Zych, 2004). According to another approach, aging is perceived as a process of progressive impairment of vital functions and loss of adaptability to environmental changes, along with an increasing probability of death (Kirkwood, 1996). In general, the condition referred to as old age is an unavoidable stage of the aging process. In turn, aging, according to psychogerontological literature, means a certain process and is dynamic, while old age as a state is static (Porzych et al., 2014). According to the life cycle theory of D.J. Levinson (Levinson, 1998), old age is one of the phases that is not homogeneous and can be divided into subsequent periods. Life cycle theory describes changes in the psyche and behavior that take place in subsequent - life-advancing - stages of an individual's life. The first phase of life is the phase of learning and gaining experience (includes childhood and adolescence). The next phase - adulthood - is the period of implementing acquired knowledge. The last phase - old age - is the regression phase. Individual phases can occur in different individuals at different times, and rigid age limits for ending or beginning individual life cycle phases cannot be specified. In contrast, the psychological concept of the life cycle - created by E. Erikson (Erikson, 2002) - divides the life of the individual into eight stages. The last stage is late adulthood and begins at the age of 60-65. It should be noted that the division of the last stage of human life changes as life increases and life improves in the elderly population. Currently, old age is divided into three phases: young old (young old) - people aged 60/65-74, old old (old old) - people aged 75-84, the oldest old (the oldest old) - people aged 85 and more. Young and old are usually still fully functional, both physically and mentally. People classified as old old are people who require help in carrying out certain everyday activities, such as shopping, cleaning and yard maintenance. The oldest old need constant help in carrying out most activities. People of this age are potential clients of institutional forms of assistance. In Poland, due to the shorter life expectancy than in Western European countries and the worse state of health of the elderly, the age from which a person requires personal assistance or assistance offered by specialized institutions in everyday existence is around 75-80 years.

In contrast to Erikson, Beauvoir (1996) did not perceive old age as a uniform period and distinguished two stages of the last phase of life, taking functional age as one of the criteria, i.e. psychophysical capabilities of the elderly: in the first phase, the elderly are functionally independent and economically independent (the so-called third age), in the second in the elderly, they are dependent, both functionally and economically (the so-called fourth age). 
As indicated by demographic forecasts - which was particularly noted in the second chapter of this work - the highest rate of population growth will occur in the so-called old-old group, i.e. in the oldest categories, aged 75 and over. As has already been noted in connection with the intensive aging of the population, creating more and better jobs is not only a political ambition, but also a necessity from an economic point of view.

\section{Demographic change and the labor market and education - an outline of the problem}

As a result of changes and long-term forecasts, according to the experts' assessment, demographic changes will have a significant impact on the future shape of education and training systems. The most serious challenge is the need to adjust all levels of education to the change in the age structure of the population due to demographic depression. Furthermore, there is a need to improve people's competences by promoting the idea of lifelong learning. As a result of the already mentioned aging of the population, it should be noted that future European labor resources will come from a population significantly older than the current. This is connected with another challenge, which is the need to update the existing training systems in order to adapt them to the needs of the aging societies from which the dominant percentage of employees will come, and the quality of their qualifications and work efficiency and Europe's competitiveness will depend on their development. An equally serious challenge is the aging of the teacher population. This process determines the need for providing high quality staff in the education system, together with the need to recruit new and talented employees in the face of market competition.

In conclusion, demographic depression is a significant challenge for numerous areas of public policy, such as family, the labor market, social security and education. The identified challenges and areas of their impact are part of a broader spectrum of reflection that should focus on a holistic approach to the education system, which is a key determinant shaping human capital, in which, as forecasts indicate, by 2050 , people over sixty-five years old will constitute $20 \%$ of the total population of all Europe.

Regardless of social changes, demographic change will put tremendous pressure on pension systems and social security in member states. If these processes are neglected, Europe is threatened with seeing lowered potential employment growth rates at around 1\% per year (Krysiak, 2007, p. 82). This forecast clearly shapes the need to address the problem of fulfilling staffing requirements. This claim is determined by the fact that the societies of developed countries are entering a phase in which the proportion of professionally active to inactive persons shifts towards the latter group. The demographic situation of Poland definitely places it in the zone of aging societies. In the coming decades, demographic trends will determine the 
shape of the economic model of the world and that of individual economies. Aging, still significant (though decreasing) number of "young" societies and countries; migration and spontaneous urbanization necessitate appropriate adjustments to economic policies. Countries with aging societies will have to make efforts to maintain citizens' standard of living, develop new types of services, as well as ensure the continuity of social security systems and the sustainability of public finances. A limited supply of economically active people and changes in the demand for employees (qualified and unskilled) will lead to an increase in global migration. Urbanization, which creates incentives for economic development, will also increase pressure on food and water resources, and when uncontrolled, may generate excessive economic and social costs (Strategy..., 2017, p. 20).

At the same time, competences related to the concept of the so-called silver economy, understood as a socio-economic system which, on the one hand, is focused on using the potential of older people on the labor market, and on the other hand, takes into account their needs as consumers (Analysis..., 2014, p. 37) must be addressed.

The productivity paradigm is changing along with the aging of developed societies, including Poland. Developed countries, if they want to maintain a standard of living and the level of GDP growth necessary for this purpose of 2-3\% per year, must radically increase the productivity of their economies. Innovation is the only way available. "McKinsey Quarterly" estimates that in the United States, product and business innovation must account for at least a 70\% increase in productivity (Bisson et al., 2010). In Western European countries, every additional euro produced must come from 100\% innovation, and in Japan, due to the rapid decline in labor force, innovations must keep up with the resulting decrease in productivity, which means the need to achieve an increase of $160 \%$ from innovation. This means a close link between the demand for competences and innovation. In this context, attention should be paid to one of the most important (in the opinion of the European Commission) challenges facing Poland, is providing a fix for the currently unattractive research and innovation system and the low innovation potential of Polish small and medium-sized enterprises (Position Paper...). As the Strategy for Responsible Development emphasizes, the biggest challenge for Poland will be achieving the assumed level of expenditure on research and development activities (hereinafter R\&D), which is also a problem across the EU. In recent years, many changes have taken place in Poland that have positively influenced the innovativeness of the Polish economy and the ability to think about innovations. There was an acceleration of the process of catching up in enterprises, including by renewing the machine park, building a new R\&D infrastructure, as well as strengthening the competences of staff implementing innovative projects. This was done with a large share of EU funds. The way of thinking about innovations is also gradually changing - besides the absorption of ready technologies, enterprises see the need to develop their own solutions, including those based on the results of R\&D self-works, and build a competitive advantage on them. In order to support these processes and concentrate resources on selected areas, using analytical tools such as technological foresight, and through constant 
cooperation with business and science, key technology areas called national smart specializations can be recognized and developed (Strategy..., 2017, p. 45).

\section{Demographic change - the Śląskie Voivodeship}

Demographic development in Poland and the Śląskie Voivodeship in the 90s of the last century was clearly inhibited and seriously transformed compared to previous years (Skibiński, 2012, pp. 144-155). As Anna Runge notes, a retrospective study of population changes as well as their broader socio-economic background allows for appropriate generalizations. And so, in the trend of demographic work, especially in recent years, the thesis about the qualitative change in population trends is noteworthy. It begins in 1982, when for the last time other voivodships significantly mark their share in supplying the regional labor market of the Katowice voivodship. The closing of this market has its national causes, i.e. the crisis of the 1980s. In addition to growing economic problems, the dynamics of population transformation has decreased (Runge, 2010, p. 35).

In 1991, the Katowice Province reached the maximum of its post-war population, after which a demographic regression began. Two years later (1993), for the first time in the history of the region, a negative migration balance occurred. The tendency to move to urban centers, especially the largest cities of the Katowice conurbation, is clearly decreasing. The "focus" of migrant interests is shifting to rural areas. In this context, it is worth noting that the ongoing demographic and social transformations are the effect of four basic overlapping interactions, i.e. business cycles, globalization, demographic transition II and suburbanization (Krzysztofik et al., 2012). The end of the 1980s and the first decade of the 1990s brought a decrease in the population of 4900.1 thousand in the Śląskie Voivodeship down to 4797.7 thousand persons, i.e. by $-2.1 \%$. The decrease mainly concerned the population living in cities $(-3.9 \%)$. Rural areas were characterized by an increase in population, which in the analyzed period amounted to $+5.7 \%$. There were two reasons for these changes. The first was administrative changes leading to the separation of rural areas that were in previous periods incorporated administratively in the cities (Runge, 2014). The second reason is be found in the significant weakening of the labor market, which, as noted by J. Runge, was a magnet attracting migrants (Krzysztofik et al., 2012). Under these conditions, the Silesian Province was created in 1998, formed as a result of the merger of the former Katowice, Bielsko and Częstochowa provinces (Law of..., 1988).

In terms of the urban network, the Śląskie Voivodeship is a unique region in Poland. Following R. Krzysztofik, the following facts determining his specificity can be mentioned (Krzysztofik, 2006, pp. 16-21): 
- It is the most urbanized region of Poland. The density of the urban network is also the highest in the country, which is expressed by the $\mathrm{km}^{2}$ of territory per one city.

- The number of cities, amounting to 71 , is inferior to the Wielkopolskie Voivodship, which, however, has three times the area.

- There are complex agglomerated systems in the form of conurbations (Katowice conurbation), polycentric agglomerations (e.g. Rybnik agglomeration), microconurbations (Radlin - Pszów - Rydułtowy) and urban complexes (Zawiercie Myszkowski). In addition, there are two large monocentric agglomerations - BielskoBiała and Częstochowa.

- The share of cities that arose as a result of 19 th and 20th century industrialization is large.

- The average city administrative area is clearly above the national average A large group of highly specialized industrial cities occur here.

- There is a specific category of rural and urban communes that were established in the 1990s as a result of the breakup of large cities (Jarczewski, 2002).

The former Katowice Province makes up the largest part of the area of Sląskie Voivodeship (46.9\% of the total area). However, larger disparities are marked in terms of the share of population contributed by these three former voivodships. The clear dominance of the former Katowice voivodship covering as much as $73.7 \%$ of the total population of the Śląskie voivodship is accompanied by a small and similar share of the other two voivodships $(12.6 \%$ and $13.8 \%$ ). It should be emphasized that if we sort out individual cities and rural communes of the Śląskie Voivodship according to population density, we will obtain a number that allows to conclude that half of the voivodship's population (49.8\% of the total population) lives on only $10.4 \%$ of its area. In contrast, half of the voivodship's area (50.3\% of the total area) is inhabited only by $10.0 \%$ of its population (Rumge, 2014).

Table 1.

Components of the birth rate in the Ślaskie Voivodeship in the years 1978-2017

\begin{tabular}{|c|c|c|}
\hline Specification & Summer & Silesian Voivodeship (Thous) \\
\hline Population & 1978 & 4535,5 \\
\hline Natural increase balance & \multirow{2}{*}{$1979-1988$} & 338,7 \\
\hline Balance of migration & & 136,5 \\
\hline Population & 1988 & 4900,1 \\
\hline The sum of the natural increase & \multirow{2}{*}{ 1989-1998 } & 46,5 \\
\hline Balance of migration & & 12,3 \\
\hline Population & 1998 & 4797,7 \\
\hline The sum of the natural increase & \multirow{2}{*}{$1999-2008$} & $-46,6$ \\
\hline Balance of migration & & $-96,3$ \\
\hline Population & 2018 - first half of the year & 4540,1 \\
\hline The sum of the natural increase & \multirow{2}{*}{$2008-2017$} & $-5,5$ \\
\hline Balance of migration & & $-11,4$ \\
\hline
\end{tabular}

Source. A. Runge, Processes and population structures in the Śląskie Voivodeship, in: Demographic and social processes and structures in the Śląskie Voivodeship in 1988-2008, ed. Statistical Office in Katowice, Katowice 2010, p. 55 and own calculations based on the CSO Local Data Bank. 
In the years 2004-2017, the downward trend in the number of people living in the Sląskie Voivodeship deepened. During this period, the total population decreased by 152,591 people. Compared to 2004 , this was a $3.2 \%$ drop in the total population of the Śląskie Voivodeship. However, compared to the end of the 1980 s, this loss was $7.2 \%$, i.e. nearly 352 thousand people. In Śląskie's cities, the trend of a further decline in population was also perpetuated. Rural areas in the period under assessment remained the model of previous years under the influence of population growth.

All told, the population density in the Śląskie Voivodeship decreased from 399 people per $\mathrm{km}^{2}$ in 1988 to 369 people per $\mathrm{km}^{2}$ in 2017 . This is a decrease of $7.5 \%$. The voivodship's share in the population of the country also diminished, going from $12.9 \%$ in 1988 , to $11.8 \%$ in 2017 . This indicates the existence of a greater severity of adverse demographic trends in the Sląskie Voivodship compared to other areas of the country. As it was noted earlier, until 1988, the population increased, and then in the period of political and economic transformation, the processes of population stagnation and, soon, the deepening demographic regression, were initiated.

The reasons for such a strong decline in the number of younger generations include (Processes and structures..., 2010):

- the demographic of the 1990s (entering the reproductive age of the lowland generation of the 1960s),

- intensification of moral changes (consumer lifestyle, secularization) and changes related to the economic transformation (availability to employers, fear of losing a job),

- rising living costs in conditions of economic hardship and rising unemployment.

In turn, the intensification of demographic aging processes results from the impact of several further factors, these being (Labor market..., 2013):

- intensification of social changes affecting the reproductive pattern bringing about a situation of generational biological unsustainability, which has reduced the number of younger generations. These changes occurred most strongly in the voivodship's cities,

- effects of the demographic decline,

- the aforementioned entry into the reproductive age in the 1990 s of the previous lowland generation, which affected the small numbers of younger generations,

- stopping the migration supply to young people, or even the migration outflow of young people outside the region (mainly abroad), who, due to the lack of attractive work in the place of residence choose temporary migration - which delays the age of marriage and the birth of the first child,

- improvment of living conditions, which extended average life expectancy.

As a result of the described tendencies, one of the key components of demographic processes, which is the population growth, with the passage of years in the Śląskie Voivodeship, assumed the abovementioned negative values. In the years 1979-1988, the population growth 
in the Śląskie Voivodeship was positive and amounted to 338.7 thousand people. The years 1989-1998 brought a crisis in natural growth, which amounted to only 66.5 thousand persons, i.e. it accounted for only $19.6 \%$ of the birth rate from the previous summer. In the years 1999 2008, the natural increase again showed decline. During this period the natural loss reached the level of -46.7 thous people. The trend of permanent natural defect was consolidated in the following years, i.e. 2009-2017, which amounted to -5,500 people. It is worth noting that the first negative natural defect in the Śląskie Voivodeship was observed in 1996. From 1998 to 2017, this loss amounted to 52.1 thousand people (Sojka, 2017).

The described condition determines the development of subsequent demographic coefficients, including the fertility rate and the gross reproduction rate. In 2003, the fertility rate was only 1,100 children, and although we observed its increase to 1,424 in 2017, it still did not ensure the sustainability of generations. In this context, it is worth noting that narrow reproduction, i.e. the lack of generational substitution, is manifested in the fact that generations of children are less numerous than were the generations of their parents. This situation causes the society to die out. In turn, gross reproduction ratios of 0.704 in 2003 and 0.693 in 2017, respectively, also do not guarantee biological reproduction of the population in the Śląskie Voivodeship. This only ensures a factor of 1.0. To obtain it, the fertility rate should be maintained at 2.14 children (Rączaszek, 2012).

Along with these unfavorable processes, a clearly disturbed feminization ratio is observed in the Śląskie Voivodeship, which is another regularity affecting the future demographic situation of the province. (Hrynkiewicz et al. 2017). It is worth recalling that in the age group characterized by the highest fertility rates, i.e. 25-29 years, the feminization rate shows severe deficiencies in women, at 96 women per 100 men - identically in the 20-24 age group; to increase to 98 women per 100 men in the 30-34 age group.

In the youngest years, a decrease in the number of children and adolescents is forecasted in each age group analyzed, with the loss in all age groups of children and youth being greater than on the national scale. In the age group $0-2$ years the changes will be from $2.9 \%$ to $2.3 \%$, $3-6$ years from $4.1 \%$ to $3.2 \%, 7-12$ years $5.2 \%$ to $4.8 \%, 13-15$ years $2.7 \%$ to $2.4 \%, 16-18$ years $3.0 \%$ to $2.4 \%$ and $19-24$ years $7.5 \%$ to $5.1 \%$. According to forecasts, by 2035 , in Poland, the population of children of 0-2 years will be reduced by over $30 \%, 3-5$ years - by $25 \%$, and in the population of $6-14$ years - by about $16 \%$.

The effect of demographic depression are numerous development problems regarding the population structure of the Śląskie Voivodeship. Among them the most serious include:

- entering the retirement age of post-war baby boomers,

- further deformation of the gender structure, increase of feminization, especially in older age groups,

- limiting the replacement of generations on the regional labor market,

- persistence of adverse changes in the structure of the unemployed (university graduates) (Runge, 2015, pp. 286-287). 
More specifically, in the next few decades in Poland and the voivodship the dynamic aging process of the voivodship's inhabitants will be a permanent phenomenon. According to the CSO forecast of 2014 in 2050, the population of the voivodship aged 65 and over may increase by $20 \%$ - representing in the forecast period the percentage of over $34 \%$ of the total population of the voivodship. This state will determine in the next decade the voivodship labor market by showing a clear decline in labor supply and a dynamic increase in the demographic load indicator, which will directly shape the pressure on satisfying social security benefits and will significantly affect the reorientation of the education system, by compelling that it be adapted to the needs of the elderly. As a result of shifting individual cohorts in the demographic structure of the voivodship's population, the population of the youngest will be decreasing and the population in the senior age will increase. If the forecasts assumed above on the voivodship labor market are fulfilled, the largest decrease in the number of people aged $30-34$ by $55.6 \%$ and in the age of $25-29$ by $55.1 \%$ can be expected, and in the countryside aged 25-29 years by $39.8 \%$ and aged $22-24$ - by $37.3 \%$. Population growth (both in cities and in the countryside) will occur among people aged 85 and over (by almost $273 \%$ and over $280 \%$, respectively).

According to one forecast, in 2050 compared to 2013, Śląskie Voivodeship will see the greatest (after the Opolskie and Świętokrzyskie voivodships) decreases in the working age population (pre-working age from $16.9 \%$ to $14.3 \%$, productive from $64.1 \%$ to $55.2 \%$ and postproduction growth from $19 \%$ to $35 \%$ ) in Poland. In turn, the natural increase until the end of the forecast horizon will be the lowest in the country (a decrease from minus 6.3 thousand to minus 23.4 thousand in 2050) and the demographic dynamics ratio will decrease permanently from 0.9 , to 0.5 .

If the indicated changes come true, according to the CSO forecast, Silesia will be an example of a dramatic demographic situation and weakening human and social capital with deep social consequences until 2050. These consequences concern the depopulation of numerous cities and municipalities, mass foreign emigration, disturbances in natural movement, lack of generational replacement and the aging of the population.

\section{Conclusions}

The theories, megatrends and forecasts indicated above (it seems) unequivocally resolve the issues of the importance of scientifically shaped demographic assessments and analyzes. On their basis, it can be concluded that the effect of the regressive nature of demographic change is the growing process of demographic aging. This will affect the situation on the labor market. Occupational inactivation of numerous (high-growth) years of retirement age, following a weak supply of labor from a small number of (low-volume) years entering the working age can lead 
to quite different difficulties on the labor market - difficulties in obtaining labor, both in quantitative sense, as well as qualitative.

In the light of the observed and anticipated changes, it is important to emphasize the importance of influencing the population structure of Poland and the Ślaskie Voivodship, waving highs and demographic lows, extending the lowland phase at the end of the 1980s into subsequent years (transformation period), and the impact economic and political transformation and Poland's accession to the EU into the spatial, demographic, social, economic and infrastructural sphere, which highlighted numerous development problems. Among them, currently, as indicated by numerous studies, one of these challenges is the preparation of properly educated, personnel who will efficiently and effectively use their potential to achieve the assumed economic goals and implementation of the mission of national enterprises (Marszowski, 2018, pp. 213-240). The dominant in these activities is a modern, innovative and responding to contemporary and future challenges education system that is effective at every level of education. This must be a system which, in line with short and medium-term economic goals and megatrends, in phase II of demographic transition and globalization, determines the successful development of the two most important elements of human and social capital in the modern world and the human attitudes resulting from them - the universality of ideas, the ability to create and accumulate the most creative individuals, the best norms of behavior and, above all, to forge a climate for the fulfillment and success of the individual in the contemporary and changing world with dynamics hitherto unknown (Marszowski, 2018, pp. 5-26).

\section{References}

1. Analiza kwalifikacji i kompetencji kluczowych dla zwiększenia szans absolwentów na rynku pracy (2014). Warszawa: Agrotec Polska Sp. z o.o.

2. Beauvoir, de, S. (1996). The Coming of Age. New York: WW Norton \& Company, 7.

3. Bisson, P., Stephenson, E., Viguerie, S.P. (2010). Global Forces. McKinsey Quarterly.

4. Blacker, C.P. (1947). Stages in population growth. Eugenics Review, XXXIX.

5. Landry, A. (1934). La révolution démographique. Paris: Sirey.

6. Thompson, W.S. (1929). Danger Spots in World Population. New York

7. Knopf, A.A., Notestein, F.W. (1945). Population. The Long View. In: T.W. Schultz (ed.), Food for the World. Chicago: Chicago University Press.

8. Sauvy, A. (1952/1954). Théorie générale de la population. Paris: PUF.

9. Wittthauer, K. (1959). Zur geographischen Differenzierung der Bevölkerungsdynamik, Petermanns Geographische Mitteilungen, COIII, 4.

10. Eberhardt, P. (2014). Fazy rozwoju demograficznego Polski. Roczniki Nauk Społecznych 6(42), 2. 
11. Erikson, E.H. (2002). Dopetniony cykl życia. Warszawa: Rebis.

12. Hrynkiewicz, J., Potrykowska, A. (eds.) (2017). Sytuacja demograficzna województwa śląskiego jako wyzwanie dla polityki społecznej i gospodarczej. Warszawa: Rządowa Rada Ludnościowa/The Government Population Council.

13. Jarczewski, W. (2002). Odzyskana niezależność - przyczyny i skutki powstawania nowych gmin na obrzeżach GOP w latach 90. Kraków: Dante.

14. Kaa, D.J. van de (1987). Europes Second Demographic Transition. Population Bulletin, 42, 1. Washington: Population Reference Bureau Inc.

15. Kirkwood, T.B. (1996). Human Senescence. BioEssay, 18.

16. Krysiak, I. (2007). Wyzwania współczesnego rynku pracy. In: J. Tokarz (ed.), Rynek pracy a osoby bezrobotne 50 plus. Bariery i szanse. Warszawa: Akademia Rozwoju Filantropii w Polsce.

17. Krzysztofik, R. (2006). Miasta. In: M. Tkocz (ed.), Województwo Ślaskie, Zarys geograficzno-ekonomiczny. Sosnowiec: Wydział Nauk o Ziemi Uniwersytetu Śląskiego.

18. Krzysztofik, R., Runge, J., Kantor-Pietraga, I. (2012). An Introduction to Governance of Two Polish Cities: Bytom and Sosnowiec. Sosnowiec: Wydawnictwo Uniwersytetu Śląskiego.

19. Levinson, D.J. (1986). A Conception of Adult Development. American Psychologist, 41(1).

20. Mączyńska, E. (2010). Przełom cywilizacyjny a wzrost gospodarczy. Niedoceniane aspekty demograficzne. Biuletynu Rządowej Rady Ludnościowej, 55.

21. Marszowski, R. (2018a). Edukacja i aktywna polityka społeczna wobec wyzwań rozwojowych $w$ powiecie pszczyńskim. Warszawa: Międzynarodowe Studia SpołecznoHumanistyczne Humanum.

22. Marszowski, R. (2018b). Kadry kwalifikowane na rynku pracy. Najcenniejszy zasób współczesnych gospodarek. Warszawa: Międzynarodowe Studia SpołecznoHumanistyczne Humanum.

23. Porzych, K., Kędziora-Kornatowska, K., Porzych, M. (2004). Psychologiczne aspekty starzenia się i starości. Gerontologia Polska, 12.

24. Stanowisko służb Komisji w sprawie opracowania umowy o partnerstwie i programów w Polsce na lata 2014-2020.

25. Procesy i struktury demograficzno-społeczne na obszarze województwa śląskiego w latach 1988-2008 (2010). Katowice: Urząd Statystyczny.

26. Prognozowanie i symulacje, http://www.woiz.polsl.pl/ asojda/pis_wyklad.pdf, 13.05.2019.

27. Rączaszek, A. (ed.) (2012). Demograficzne uwarunkowania rozwoju społecznego. Zeszyty Naukowe Wydziałowe Uniwersytetu Ekonomicznego w Katowicach.

28. Raport na temat sytuacji osób starszych w Polsce (2012). Warszawa: IPiSS.

29. Runge, A. (2014). Encyklopedia Województwa Śląskiego, Tom 1. Instytut Badań Regionalnych Biblioteki Śląskiej. 
30. Runge, A. (2012). Procesy i struktury ludnościowe w województwie śląskim. In: Procesy i struktury demograficzno-społeczne na obszarze województwa śląskiego w latach 19882008. Katowice: Urząd Statystyczny.

31. Runge, J. (2015). Regionalne i lokalne konsekwencje współczesnych przemian demograficznych Polski. Elementy metodologii badań. Przykład województwa śląskiego. Studia Ekonomiczne. Zeszyty Naukowe Uniwersytetu Ekonomicznego w Katowicach, 223.

32. Kiełkowska, M. (ed.) (2013). Rynek pracy wobec zmian demograficznych. Zeszyty Demograficzne, 1. Warszawa: Instytuty Obywatelski.

33. Schlotter, M., Schwerdt, G., Wößmann, L. (2008). The Future of European Education and Training Systems: Key Challenges and Their Implications.

34. Skibiński, A. (2012). Rozwój ludności województwa śląskiego w okresie transformacji systemowej. In: Demograficzne uwarunkowania rozwoju gospodarczego. Zeszyty Naukowe Wydziałowe Uniwersytetu Ekonomicznego w Katowicach.

35. Sojka, E. (2017). Ocena zmian demograficznych w Polsce w latach 1950-2013 za pomocą metod wielowymiarowej analizy porównawczej. Studia Ekonomiczne. Zeszyty Naukowe Uniwersytetu Ekonomicznego w Katowicach, 324.

36. Strategia na rzecz Odpowiedzialnego Rozwoju do roku 2020 (z perspektywa do 2030 r.). Dokument przyjęty uchwałą Rady Ministrów w dniu 14 lutego 2017.

37. Ustawa z dnia 24 lipca 1998 r. o wprowadzeniu zasadniczego trójstopniowego podziału terytorialnego państwa (Dz.U. 1998, nr 96, poz. 603).

38. Zych, A. (2004). Moderacja rozwoju - wyzwaniem dla gerontologii edukacyjnej. Gerontologia Polska, 12. 